\title{
ANTITHETICAL FEMININE-URBAN IMAGERY AND A TALE OF TWO WOMEN-CITIES IN THE BOOK OF REVELATION
}

\author{
Gordon Campbell
}

\begin{abstract}
Summary
A major theme of the Book of Revelation is the woman-city, ${ }^{1}$ incorporating various women and cities in the unfolding story. The women are Jezebel, 2:20-23; the woman clothed with the sun, 12:1-6; the whore astride the monster, 17:1-6; and the bride, 19:6-9a, 21:9-10. The cities include seven Church-cities in Roman Asia, 2:1-3:22; Jerusalem, 11:1-13; Babylon, 14:8; 18:1-24; and New Jerusalem, 2122. Revelation integrates them all into an unprecedented orchestration of a binary motif borrowed from prophetic denunciations of ancient cities - Yahweh's marriage to his beloved people and that people's spiritual adultery. The result is both a complex blending of feminineurban imagery and a double metaphor whose fullest development is an elaborate literary contrast between two women-cities, Babylon-thewhore and New Jerusalem-the-bride. Sustained antithetical parallelism conditioning theme development ${ }^{2}$ makes the woman-city a fundamentally ambiguous reality and a powerful dramatisation of sinful
\end{abstract}

\footnotetext{
1 For OT usage, see below. The combined motif of a city and a married woman also occurs in 4 Ezr. 9:38 and 10:54. Celestial Zion, hidden near God, is pictured in 2 Esd. 9:52-53 and 10:49.

2 Antithetical parallelism conditions all of Revelation's principal literary themes, as I have illustrated with two recently published studies in French and two in English. For how the two monsters of ch. 13 are a split caricature of the Lamb, see my article 'Un procédé de composition négligé de l'Apocalypse de Jean: repérage, caractéristiques et cas témoin d'une approche parodique', ETR 77 (2002): 491-516. On reading Revelation thematically and for discussion of one major theme, the adoration of God and the Lamb and its counterfeit, see my article 'Pour lire l'Apocalypse de Jean: l'intérêt d'une approche thématique', Revue Réformée 224 (2003): 43-65. Finally, a two-part article in successive numbers of IBS 25 (2003): 60-73 and 106-120 charts the important theme of 'True and False Proclamation in the Book of Revelation' throughout the book.
} 
humanity's fickle response to God. For believing inhabitants of earthly cities, tragic tension between the call to faithful belonging and the lure of idolatrous affiliations is ultimately resolved through doubly faithful divine action which removes the squalid whore-city, Babylon, and establishes the glorious bride-city, New Jerusalem.

\section{Introduction}

In a grand fresco of the economy of salvation which pictures Isaiah 1:21 in reverse, Revelation's closing chapters depict the demise of a caricatural city, Jerusalem-the-whore (nicknamed Babylon) and the descent of the real thing, faithful New Jerusalem-the-bride. Scholarship has often taken account of the more obvious antithetical correlations that result. ${ }^{3}$ However in earlier scenes, long before Babylon appears or is replaced by her positive counterpart, various prior female figures and personified cities have progressively contributed to Revelation's comprehensive development of the woman-city metaphor. This buildup has not received the attention it merits, ${ }^{4}$ nor has the developing feminine-urban imagery ever been fully integrated with the climactic tale of two antithetical women-cities which provides its crowning touch. To compensate, the present article offers context-sensitive thematic exegesis in which inner-textual and inner-canonical reading strategies are combined.

3 Two examples will suffice. A. M. Farrer, A Rebirth of Images (London: Dacre, 1949): 213, 'Babylon is the parody of Zion.' And fifty years later J. L. Resseguie, Revelation Unsealed: A Narrative-critical Approach to John's Apocalypse (Leiden: Brill, 1998): 77, 'Babylon and Jerusalem represent the two alternatives for humankind. Babylon, the satanic parody of the ideal city, the earthly counterpart to Jerusalem, strives to be like the heavenly city but falls far short [and] ... symbolizes humankind's lust for deification.'

4 All of the following do go some way towards our goal here: C. Deutsch, 'Transformation of Symbols. The New Jerusalem in Rv 21:1-22:5', ZNW 78-79 (1987-88): 106-126 (especially 123-124); R. J. Bauckham, The Theology of the Book of Revelation (Cambridge: CUP, 1993): esp. 126-132; and with equal subtlety G. K. Beale, The Book of Revelation (Grand Rapids/Cambridge: Eerdmans/Paternoster, 1998): 1063-65, 1117-21. For literary links between Revelation's female figures, see also Resseguie, Revelation Unsealed: 137-145; and most recently P. B. Duff, Who Rides the Beast? Prophetic Rivalry and the Rhetoric of Crisis in the Churches of the Apocalypse (New York, 2001): 87-89. 


\section{Seven Church-cities and Jezebel}

In the developing story of Revelation, the end-time Church-city of New Jerusalem in the book's denouement finds careful cumulative anticipation beginning with the Churches-in-cities of the inaugural septet. This means that from the start ecclesial and urban connotations merge into one another. On the Lord's Day, amid the din of city life in Ephesus and her sister-cities, a sevenfold beloved forgetful of her first love (Rev. 2:4) and in need of some correction (3:19) is visited by the risen Messiah and by the Spirit. These two exhort her to faithful living where she is, mirroring her ultimate citizenship in a Church-city not made with hands. The individual oracles all nuance the overall picture.

'Satan's throne' (2:13) makes Pergamum, for example, the opposite of the city where God has chosen to dwell, i.e. Jerusalem. ${ }^{5}$ In the oracle to this flourishing pagan metropolis comes the first reference to idol feasts, debauched rites and religious infidelity (2:14). Philadelphia, a Church-city which like Smyrna receives no reproach, enjoys unlimited access (3:8) in contrast to exclusion by false Jews (3:9) and is promised entry to New Jerusalem (3:12), one might say through the doors (22:14). Her victor's blessing entails being a temple pillar which, given the temple's abolition in the end-time city (21:22), means enjoying the divine presence. The triple name she is given to bear (God's name/God's city's name/a new name) unites her with God and the Lamb's wife in chapter $21 .{ }^{6}$ Here, too, the coming bride-city's identity receives its first explicit adumbration as New Jerusalem descending from God in heaven. As first-fruits foretell a harvest, so what Messiah promises to do in the anticipatory Church-city of Philadelphia will be realised in eschatological New Jerusalem.

For the last message to Laodicea, John adopts the prophetic metaphor of conjugal infidelity used to denounce unfaithful Israel, with talk of shameful nudity (3:17-18; cf. Ezek. 16:8, 35, 37; 23:10, 18, 29; Hos. 2:9; Nah. 3:5; Hab. 2:15). The only Church to receive no commendation, just stinging rebukes, Laodicea is a foretaste of Babylon $^{7}$ and an anti-image for heavenly Jerusalem, her replacement. Thus her boasted wealth anticipates Babylon's, which will evaporate at

5 Similarly J.-P. Prévost, L'Apocalypse (Paris: Cerf, 1995): 45.

6 For this interpretation, see H. Kraft, Die Offenbarung des Johannes (Tübingen: Mohr, 1974): 83.

7 Cf. J. Sweet, Revelation (London: SCM, 1979): in loc. 
her fall (18:17). Her dire need of white garments (3:18) hints at the exchange of Babylon's purple and scarlet for New Jerusalem's fine linen. Pure gold to be obtained from Messiah is the material of which the heavenly city will be made $(21: 18,21)$. Finally the prospect of her covenant meal with Messiah, who is at the door $(3: 20)^{8}$, will be fulfilled in God and the Lamb's unending presence with redeemed humanity in New Jerusalem.

Woman-city imagery is most evident in the central message to Thyatira, least illustrious of the seven Asian cities but pivotal Churchcity for this septet (2:18-29). The message's inordinate length is due largely to Jezebel $(2: 20-24)$, her lovers $(2: 22)$ and children $(2: 23)$. Three features make her a prototype of Babylon-the-whore. First, her teaching leads astray into adultery and idolatry $(2: 20)$, which makes her a deceiver like the satan and its false prophet $(13: 14 ; 19: 20)$ and more especially, like Babylon whose hocus-pocus sidetracks the nations (8:23). Secondly, she too indulges in prostitution and witchcraft, for which Jehu had destroyed the original Jezebel (2 Kgs 9:22). And like the whore-city, she assassinates the Lord's prophets (2 Kgs 18:13). ${ }^{9}$ Jezebel also hailed from Tyre, denounced in Isaiah 23, whose traits are transferred to Babylon in Revelation $18 .{ }^{10}$ The verdict given against her and her followers (in 2:22-23) anticipates the judgement narrated in chapter 18, for Babylon's associates also risk retributive justice if they

8 Sweet, Revelation: in loc., gives the following suggestive parallels: a coming in judgment (Mark 13:29; Jas 5:9), Bridegroom-Messiah's coming (Luke 12:35-48; Matt. 25:1-46) and the bridegroom knocking (Song 5:2-3).

9 For Beale, Revelation: 262, she represents an idolatrous system that John will later label as 'Babylon'. Duff, Who Rides the Beast?, considers Jezebel and Babylon to be a pair: 'John ties "Babylon" and "Jezebel" closely together so that in the reader's mind they are virtually equivalent (p. 92).' Thus Jezebel is the real target, with John attacking her via a 'rhetoric of exclusion' (126ff.) involving three contrasting metaphorical or mythological feminine figures. I endorse Duff's main correlations between Revelation's female figures, but his un-argued postulate that 'Jezebel' is John's real-world opponent in the orbit of the Asian Churches no more convinces me than the same idea did R. H. Preston and A. T. Hanson in their time, The Revelation of St. John the Divine (London: SCM, 1945): in loc.

10 An audacious recent identification of Jezebel, the Nicolaitans, Balaam and the synagogue of Satan is offered by M. Barker, The Revelation of Jesus Christ (Edinburgh: T\&T Clark, 2000): 96-102. Jezebel is Lydia of Thyatira, the merchant of purple - whose dyes came from Tyre - converted by Paul (Acts 16); Balaam is Paul the deceiver, liberal in his attitude to idol meats and to Torah in general; the synagogue of Satan is the Gentile Christian community that takes itself to be the real Israel. Barker correctly presupposes inter-Jewish polemic in Asia, but I read it quite differently as John throwing back at 'true Jews' their accusations and opposition to Jesus as Messiah and to mixed congregations. 
do not abandon her and her $\sin (18: 4,8)$. In both cases justice is dealt out on the same principle, 'according to your/her deeds' $(2: 23 ; 18: 6){ }^{11}$

As Revelation's first female figure, Jezebel crucially precedes both the heavenly mother figure of the trumpets septet and the Lamb's betrothed in the final visions. She also prefigures the whore who has similar characteristics and who parodies both mother and betrothed. Jezebel is an equivocal mother (2:23) in the sense that her children are inimical to the associates of the heavenly woman's child-ruler (12:5). She leads others astray $(2: 20,24 ;$ cf. $12: 9 ; 18: 23)$ with her porneia (2:20-22) which will typify the so-called motherhood of the whore-city $(17: 1-2,5)$, over against the virginity of the eschatological woman-city $(21: 2,9)$. Her name, Jezebel, has bloody historical connotations reflected in her own destruction $(2: 22-23 ; 17: 16)$, but in the ultimate woman-city death will be no more (21:4). Lastly, eating idol meat like Babylon drinking saints' blood (17:6) - flagrantly contrasts divine nourishment of the refugee woman $(12: 6)$ or of heavenly Jerusalem $(21: 7 ; 22: 1-2) .^{12}$

Taken together, the Church-cities of the opening septet also show the ambiguity of living as God's people in man-made cities. The seven present contrasting spiritual health checks, with two pronounced faithful (Smyrna, Philadelphia), three described in equivocal terms (Ephesus, Pergamum and Thyatira), one judged to be in a chronic (Sardis) and another in a critical state (Laodicea). Yet since all seven are Churches where Jesus walks with his people, each receives a promise to be fulfilled in 'God's dwelling place in the saints' ${ }^{13}$ (cf. 21:3), New Jerusalem, where the victors' heritage will essentially consist of being God's 'son' (21:7). Some oracles also have conditional curses which will culminate in recalcitrant Babylon's judgement and fall. Presumably, Roman Asia's cities are among the cities of the nations to fall with her in 16:19. ${ }^{14}$ As earthly Babylon empties, heavenly Jerusalem fills up, her readiness (21:2) corresponding to the

\footnotetext{
11 So also Beale, Revelation: 262.
}

12 I agree with Duff, Who Rides the Beast, ch.7 'The Women of Revelation. Binding 'Jezabel' to Babylon': 83-96, that there are four and not three feminine figures in Revelation, with two positive and two negative figures set against one another - thus Jezebel precedes the women clothed respectively in the sun, purple/scarlet and linen. See also Resseguie, Revelation Unsealed, 137-45.

13 R. H. Gundry, 'The New Jerusalem: People as Place not Place for People', NovT 29 (1987): 256-64 (256).

14 Cf. Bauckham, Theology: 126. 
prior removal of her rival the 'great city' (18:21). But as a project, the Church-city itself remains unaltered, for in the divinely crafted templeless city (21:22) where God will condescend to dwell (21:3), humanity and civilisation are spectacularly affirmed.

\section{One ambiguous 'great city'}

Not until 11:1-13 does the reader encounter the 'holy city' (11:2) and 'great city' (11:8) or its fate (11:13). Is the reader capable of recognising her? Given the extent to which the book calls forth images from prior revelation, it is difficult not to see in her, in some sense, Jerusalem. She is the royally 'great city' (Jer. 22:8; Ps. 49:1-4), still 'great' for the romanised Josephus (War vii.1.1; vii.8.7) or the Roman Tacitus (Hist. 5.2) and 'city of the great king' for Jesus (Matt. 5:35). In prophetic terms Jerusalem is 'great' as the place God chose to dwell, and therefore 'glorious' (Ps. 87:1-3). ${ }^{15}$ 'Holy city', the temple's geography and reference to the Lord's crucifixion, here, can scarcely predicate any other 'great city' than Jerusalem. ${ }^{16}$

Yet 'great' is surely an ironic epithet, as it was for 'Babylon' in Daniel 4:30. The holy city is trampled by pagan nations, as Jesus foresaw for Jerusalem (Luke 21:24), while her holiness is provisional and imperfect, as the sobriquets Sodom and Egypt show (Rev. 11:8). Among the prophets, Judah was nicknamed after that epitome of vice Sodom (Gen. 19; Isa. 1:9-10), as likewise Samaria (Ezek. 16:46, 55), whilst Zion could surpass Sodom in sin (Lam. 4:6). Egypt, meanwhile, was synonymous with servitude and oppression.

Thus the 'great city' is anything but holy, as murderess of the prophets (Rev. 18:4; cf. Matt. 23:34-35; Luke 13:34), and anything but

15 Jer. 22:8 (LXX) and Sib. Or. 5.154, 226, 413, call Jerusalem $\dot{\eta} \pi$ ó $\lambda$ เৎ $\dot{\eta} \mu \varepsilon \gamma \alpha \dot{\lambda} \eta$. Most recent commentators decipher Revelation's next seven references to the 'great city', 'Babylon' $(16: 19 ; 17: 18 ; 18: 10,16,18-19,21)$ as references to Rome. More nuanced is the treatment of J.-P. Ruiz, Ezekiel in the Apocalypse: The Transformation of Prophetic Language in Revelation 16:17-19:10 (Frankfurt: Lang, 1989): 281-289; he sees the 'great city' theme as follows: 11:2, 8, 13 (Jerusalem); 14:8 (Rome); 16:9 (Jerusalem and Rome juxtaposed); 17:5, 18; 18:2 (after transition, Rome); 18:10, 16, 19 (assimilated to Rome); 18:21 (Rome); 20:9; 21:2; 21:10 (New Jerusalem). Cf. L. L. Thompson, The Book of Revelation: Apocalypse and Empire (Oxford/New York: OUP, 1990): 82: 'Great city usually refers to Babylon (17-18) but may refer to either Babylon or Jerusalem'.

16 Contra Beale, Revelation: 591, who sees 'the ungodly world, and not the earthly city of Jerusalem'. 
'great' since she is handed over to unbelievers. In Revelation's plot, it is particularly her fall which is 'great' $(14: 8 ; 18: 2,10,16,19,21)$. Jerusalem had ancient renown and a future destiny as a city of justice and faithfulness (Isa. 1:21, 26-27) where the Lord chose to dwell with and be encountered by his people (cf. Isa. 60:14). Nonetheless Isaiah does not hesitate to call this 'faithful city' a 'harlot' in the one breath (Isa. 1:21). Revelation's Jerusalem, too, is fundamentally an ambivalent reality, in the past and present, to which the future, renewed Jerusalem of the finale will antithetically correspond. And just as was the case in Israel's history, Jerusalem and Babylon are intimately related in Revelation, in such a way that the latter can mean the former. ${ }^{17}$ As the city which puts Jesus to death, Jerusalem in 11:8 becomes or is assimilated to Babylon, the archetypal city opposed to God and his people. ${ }^{18}$ This may be detected in her partial fall (11:13) during an earthquake, ${ }^{19}$ a collapse which anticipates the refrain of 14:8 and later 18:2 concerning Babylon and, in the interim, foreshadows the splitting apart of the 'great city' and the fall of other cities of the nations (16:19).

With 'Babylon the great, mother of whores' in 17:5, the amalgamated feminine and urban imagery of the woman-city metaphor becomes explicit. For the reader, the book's very next reference to the 'great city' confirms their equivalence (17:18), shifts the focus from 'woman' to 'city' and prepares for prolonged attention to 'Babylon the great'. Each of three oracles of woe then begins with an identical reference to the 'great city' $(18: 10,16,19)$. She is variously described as a haunt of demons synonymous with impurity $(18: 2,5)$, in contrast

17 For R. J. Bauckham, The Climax of Prophecy (Edinburgh: T\&T Clark, 1993): 208, the contrastive parallelism of $11: 13$ and 16:18-21 fuses together the horizons of Jerusalem and Babylon: 'If the great city of chapter 11 has some of the characteristics of Jerusalem, it also has those of Babylon: John's purpose here is to merge rather than to distinguish the two cities.' Moreover, a close study of the characteristics of 'Babylon' in Revelation (14:8; 16:19; 17:2-7, 15-16, 18; 18:2-4, 6-8, 16, 20, 24) suggests that only Jerusalem fits them all. On this, see A. M. Ogden, The Avenging of the Apostles and Prophets (Somerset, 1985): 435-451.

18 Similarly J. Ellul, Sans feu ni lieu (Paris, 1975): 206. B. Malina, The New Jerusalem in the Revelation of John: The City as Symbol of Life with God (Collegeville: Liturgical, 2000): 70, notices how Babel as archetype affects Babylon in Revelation: 'The first city created by human beings after the Deluge ... first city of our era of human-kind ... first city of the postdiluvial period finds its contrast with the final city, the celestial Jerusalem.'

19 Note the intriguing parallel with Jesus' resurrection in Matt. 28:2; cf. Bauckham, Climax: 208. 
to New Jerusalem's unsullied purity (21:27), as God's habitation (21:3) and as a place the faithful must forsake (18:4) before judgement sanctions her unjust acts (18:8). Denuded and deserted (18:16, 19), she becomes the object of empty lamentation as a late great city (18:18) silenced like Tyre before her (Ezek. 27:32).

\section{Contrasting figures: A celestial mother and a gaudy whore}

Revelation 12:1-2 delineates the traits of a magnificent female figure which brings new depth and breadth to John's feminine-urban metaphor. Her grandeur reflecting sun, moon and stars gives her galactic glory ${ }^{20}$ as queen of the cosmos, yet despite her splendour the pains of childbirth which also make her a mother evoke vulnerability. A huge dragon intends to take full advantage of this (12:3-4), creating havoc in the sky as a third of the stars fall. The woman brings forth her child destined for royalty, like Zion's daughter in Micah 4:6-10 and 5:1-3 or Jerusalem in Isaiah 66:7-9, ${ }^{21}$ and he successfully escapes the dragon's clutches ${ }^{22}$ (Rev. 12:5; cf. 2:27). As for the woman, providential refuge and succour are also hers in an earthly desert (12:6), beyond reach of the dragon's rage (12:13-14), while the earth comes to her rescue when she is attacked (12:15-16). The woman's passivity and the emphasis upon her fate are striking.

The whole scene, whatever its overtones of an international stellar myth, ${ }^{23}$ develops the primeval scenario of the serpent, Eve and her

20 B. J. Malina and J. J. Pilch, Social Science Commentary on the Book of Revelation (Minneapolis: Fortress, 2000): 155ff., outline the importance of Andromeda, the constellation of the pregnant woman, in ancient Mesopotamian, Egyptian and GrecoRoman astronomy.

21 The Isaiah Targum glosses this as the birth of the messianic king; see P. Prigent, L'Apocalypse de St. Jean ( $3^{\text {rd }}$ edn; Geneva: Labor et Fides): 287.

22 This is heard as an echo of Jehosheba's rescue of baby Joash, in $2 \mathrm{Kgs} \mathrm{11:1-3,} \mathrm{by}$ J. E. Bruns, 'The Contrasted Women of Apocalypse 12 and 17', CBQ 26 (1964): 459463, esp. p. 460.

23 Commentators have urged John's adaptation here of the ancient myth of the queen of heaven and her divine child. See e.g. D. E. Aune, Revelation, vol. 2 (Word Biblical Commentary; Nashville: Nelson/Word, 1997-98): 667-674, excursus 'The Combat Myth and Revelation 12'. Some also draw a parallel with the description of Isis found in Apuleius' Metamorphoses. As for the woman's identity, its collective nature has always commanded general assent. Thus Victorinus launched the history of interpretation of Rev. 12:1-2 as follows: 'ecclesia est antiqua patrum et prophetarum 
offspring in Genesis 3:15-16a. Accordingly, the woman is a symbol for humanity as a whole in its ambiguous relationship to God. Revelation's developing plot confirms this, for Jezebel and now the celestial mother figure will give way to the great whore and the Lamb's spotless bride. ${ }^{24}$ The move from the second to the third 'woman' is achieved by deliberate and careful linking of the 'great sign' in 12:1 with the 'mystery' in 17:5. Evidence for this is provided by the following antithetical correspondences:

1. The woman ( $\gamma \cup v \eta \dot{)})$ threatened by the red dragon $(12: 4,13-17)$ is given refuge and nourished in a desert $(12: 6,14)$. In the same setting, but with negative connotations as a cursed lair of demons, ${ }^{25}$ another woman $(\gamma \cup v \alpha \hat{i} \kappa \alpha)$ appears (17:3). By contrast she feeds herself on blood and bestrides the dragon's double - a seven-headed, ten-horned scarlet monster - but only till it treacherously makes her its prey $(17: 16){ }^{26}$

2. In $12: 4 \mathrm{~b}-5,13$ the woman is mother to Messiah and then in 12:17 to further offspring characterised by obedience to God and faithfulness to Jesus and persecuted for it. The so-called maternity of the whore's mother, her anti-image, entails getting drunk on the blood of the former's children (17:5-6) - saints and witnesses hunted like dragon's prey, 12:17 - whilst mothering a counter-community $(17: 15)^{27}$ whose distinguishing mark is infidelity. ${ }^{28}$

3. One clothed woman ( $\gamma \cup v \grave{\eta} \pi \varepsilon \rho \mathrm{r} \beta \varepsilon \beta \lambda \eta \mu \varepsilon \dot{v \eta})$ is a foil for the other. The celestial garb of the first woman, bedecked with the sun, moon and twelve stars $(12: 1)$, is patently contrasted by the gaudy attire and overdone jewellery of the whore (17:4). In 18:16 the addition of 'fine

et sanctorum apostolorum'; and in our day Beale, Revelation: 631, sees in her 'the community of faith in the Old and New Testaments.'

24 See E. Corsini, The Apocalypse (Wilmington: Michael Glazier, 1983): in loc.

25 On the desert's ambivalence, see Resseguie, Revelation Unsealed: 80-81: 'a place of divine absence and disfavour on the one hand, or a sanctuary of safety and protection, on the other'.

26 Similarly Beale, Revelation: 857.

27 Cf. G. R. Beasley-Murray, The Book of Revelation (London: Marshall, Morgan \& Scott, 1974): 197: 'Both represent communities, the former possessing a heavenly calling, the latter being an agent of hell.'

28 Thus Beale, Revelation: 859: 'The Babylonian mother spawns faithless children, whereas the mother of ch. 12 produces faithful offspring.' 
linen' (from Ezek. 16:10,13) gives her an even closer resemblance to unfaithful Zion clad in scarlet and adorned with gold (Jer. 4:30). ${ }^{29}$

4. The male child's mother undergoes protracted but ineffectual persecution (Rev. 12:13-17) whereas the whore is a passive victim who will fall prey to the monster's treachery. ${ }^{30}$

Cumulatively, these antitheses ensure that the reader spots the counterpoint of 'contrasting feminine paradigms' 31 by which the whore is set in deliberate opposition to the celestial woman. ${ }^{32}$ Drunkenness with the blood of her rival's descendants completes a picture diametrically opposite to that of the mother she so obviously parodies. ${ }^{33}$

Clearly, Revelation's feminine imagery is susceptible to the same reverse transformations as its urban imagery. Between two trips into the desert, 'woman' can exchange positive attributes for negative ones linked to evil, ${ }^{34}$ in a process of metaphorical extension without any interruption in continuity. Similarly the prostitute of 17:4 or the whorecity of 18:16 will be definitively supplanted by the bride-city of the denouement. By sophisticated use of antithetical parallelism our author has decomposed into two contrasting figures the one 'woman-city' which God has chosen as his bride in spite of her proclivity for the worst of infidelities.

The woman-city metaphor is rooted in the biblical habit of speaking of Jerusalem as a daughter of Zion arrayed in splendour (Isa. 52:1-2) ${ }^{35}$

29 It should also be remembered that in Jer. 4:31, Zion's daughter is about to give birth to her first-born.

30 A good summary of the antitheses remains that of G. Bornkamm, 'Die Komposition der apokalyptischen Visionen in der Offenbarung Johannis', ZNW 36 (1937): 132-149, esp. p. 135.

31 Duff, Who Rides the Beast?: 87; he sees the whore as an intentionally distorted reflection of the celestial woman. I go further, for the correspondences surely indicate to the reader the startling identity of the two figures.

32 Contra Prigent, Apocalypse: 378, who underplays the force of the antithetical correspondences.

33 Ellul, L'Architecture en mouvement (Paris: Desclée, 1975): 199-201, puts this well: 'La Femme est en effet dans le ciel l'image de la mère, et sur la terre elle est la prostituée ... [d'une part] mère de la nouvelle création, et [d'autre part] la concentration de tout le terrestre.'

34 On this, see the remarks of Thompson, Revelation: 82.

35 Cf. 4 Ezr. 10:25-27. For a recent comparative study of Jewish and Christian texts which offer apocalyptic transformations of the 'Lady-City' figure, see E. McE. Humphrey, The Ladies and the Cities: Transformation and Apocalyptic Identity in Joseph and Aseneth, 4 Ezra, the Apocalypse and the Shepherd of Hermas (Sheffield: SAP, 1995). 
or as a bride who has forgotten her first love (Jer. 2:2, 32). As a compound metaphor, it generates a double set of feminine or urban attributes $^{36}$ - as in the case of Jezebel and Thyatira - and Revelation chooses now to alternate, now to combine them. It follows that Babylon possesses double parodic potential: if, in her role as a counterpart city, she appears on the scene much as heavenly Jerusalem later will (21:9), ${ }^{37}$ as a woman (and prostitute) she counterbalances and contrasts with two female figures, the mother of chapter 12 and the wife of ensuing chapters $(19: 7 ; 21: 2 ; 22: 17){ }^{38}$ This means that although the whore's characteristics in chapter 17 form an anti-image ${ }^{39}$ of the bride in 21:9-21, they are first and foremost dictated by her obvious opposition to the heavenly woman.

\section{A brief sighting of Babylon}

The antithetical parallelism joining the whore-city of chapters $17-18$ to the bride-city of 21:9-21 is carefully engineered from chapter 14 onwards. ${ }^{40}$ First 14:1-5 lifts a corner of the veil concealing Jerusalem's eschatological salvation. In 14:3-4 her inhabitants are described in five ways, as choristers singing a new song, one hundred and forty-four thousand, pure virgins, faithful followers and redeemed. In contrast 14:6-20 proleptically envisages Babylon's future demise, anticipating it in the present, as well as God's judgement on those who bear the monster's mark. ${ }^{41}$ Drunkenness and fornication (14:8) are opposites to

\footnotetext{
36 Noticed by E.-B. Allo, St. Jean, l'Apocalypse (Paris: Gabalda, 1933): 335. Prigent, Apocalypse: 469-470, notes Revelation's preference for the traits of the whore when describing Babylon, but thinks only urban symbolism affects the picture of heavenly Jerusalem after 21:9, when the marriage has occurred. Rather, the double imagery has fused, for as J. Fekkes has shown, Isaiah and Prophetic Traditions in the Book of Revelation: Visionary Antecedents and their Development (Sheffield: JSOT Press,

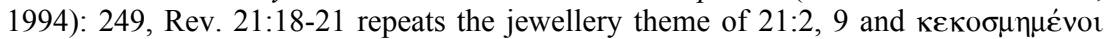

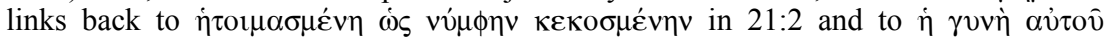

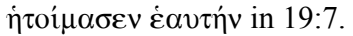

37 Allo, Apocalypse: 265, for whom the woman in ch. 12 is the 'Church-Jerusalem' and Babylon the type of an anti-Church.

38 Thus e.g. E. Lohmeyer, Die Offenbarung des Johannes (Tübingen: Mohr, 1970).

39 See Fekkes, Isaiah: 89.

40 M. E. Boring, Revelation (Louisville: WJK, 1989): 149-150, offers as proof that John regarded 12:1-14:20 as a literary unity, the seven angelic interventions of 12:7; $14: 6,8,9,15,17,18$.

41 Thus Boring, Revelation: 168.
} 
the fidelity and chastity of the Lamb's followers. ${ }^{42}$ There are further correspondences to Jerusalem in 14:8-20: the merited punishment given to all the monster's followers (14:10-11), applied in line with that inflicted on Babylon, is the strict counterpart of the recompense awaiting the righteous when New Jerusalem appears $(3: 12 ; 21: 1-22: 5$; cf. $22: 14,19) .{ }^{43}$ It should further be noted that a pressed vintage beyond the city walls (14:20) also presupposes a holy city. ${ }^{44}$

From 14:6 onwards Revelation provides a line-drawing of the prostitute which will later take on full colour and detail. Revelation 18:2 (like 18:21) echoes the refrain concerning Babylon's fall in 14:8, while the entire accompanying phrase 'she made all the nations drink from the wine of her immoral passion' is also used again in 18:3, with the usual slight variations. Preliminary sketch and full-blown portrait will once more be the pattern for the bride-city, briefly glimpsed in 19:5-10 before coming into full view from 21:9 onwards. ${ }^{45}$

\section{Women-cities: Literary composition and antecedents}

Some of the traits the whore shares with the heavenly woman combine with many others to set her in fundamental contrast to the bride who will eventually take her place. This second parody offered by the prostitute is unequalled in scope by any other cluster of antithetical thematic correlations in Revelation. ${ }^{46}$ Babylon is the focus for a complex diptych which lingers over the details of a destiny summarily set out in 16:19. This large segment comprising a vision (ch. 17) and a long funeral oration (ch. 18) develops the double symbolism of

\footnotetext{
42 Similarly R. C. Ortlund Jr, Whoredom: God's Unfaithful Wife in Biblical Theology (Leicester: IVP, 1996): 160.

43 Fekkes, Isaiah: 208, notes this correspondence.

44 E. Delebecque, L'Apocalypse de St. Jean (Paris, 1992): in loc., and Ellul, Architecture: 187, read this as a first anticipatory allusion to New Jerusalem.

45 Fekkes, Isaiah: 232, n. 20, gives the following formal parallels between the two introductions: 14:6//19:5; 14:13//19:9; cf. 14:14-20//19:11-21.

46 No doubt because New Jerusalem is Revelation's biggest picture of salvation, and Babylon its most developed picture of judgement; cf. Boring, Revelation, 178-179. Cf. also W. W. Reader, Die Stadt Gottes in der Johannes-apokalypse (Göttingen, 1971): 264: 'Gegenüber der Gottesstadt Jerusalem steht die Weltstadt Babylon, und zwar in einer solchen Weise, das für den Abschluss des ganzen apokalyptischen Dramas die Polarität civitas Dei/civitas Diaboli ausschlaggebend ist (vgl. 17:1-22:5)'. I.e. 'Over against the divine city of Jerusalem stands the worldly city of Babylon, in such a way that the polarity civitas dei/civitas diaboli plays a decisive rôle in the conclusion to the entire apocalyptic drama (cf. 17:1-22:5)'.
} 
woman/prostitute $(17: 1-7,15,16 ; 18: 3,7)$ and city $(17: 5,18 ; 18: 2,4$, $10,16,18,19,21)$. Other links reinforcing the unity of the twin panels are the prostitution of the kings $(17: 2 ; 18: 3,9)$, whose relationship to New Jerusalem will be a pure one $(21: 24-26)$, the saints' blood $(17: 6$; 18:24) and Babylon's burning $(17: 16 ; 18: 8,9,18)$.

It is the crucial importance of the climactic New Jerusalem section that dictates the large number of correlations with the whole Babylon development. The two cities correspond to and counterbalance one another as twin poles of a carefully crafted antithesis. ${ }^{47}$ The features and fates of the women-cities, from symmetrical introductions (17:1-3; 21:9-10) to parallel conclusions $(19: 9,10 ; 22: 6-9),{ }^{48}$ mirror each other in a distorted way. This is indicated in advance by matching prophetic shouts of fulfilment ( $\gamma \varepsilon$ ' which cancels the first just as Jerusalem's descent will follow Babylon's destruction. Subtlety characterises the whole composition, for when we are told that John is to see a whore, what he sees is in reality a city personified as a woman (17:1-18) and when he is promised the vision of a bride, what he discovers is a woman figured as a city. ${ }^{50}$

Literary personification through women-cities is a common feature of the Hebrew prophets. Israel, other nations or all nations assembled with Israel into a new humanity are involved. In their repeated covenant lawsuits against an unfaithful people the prophets hope that one day betrayals will end, when the Lord comes to dwell with his people. John clearly shares this expectation (cf. Rev. 21:3). ${ }^{51}$ In Hosea 2, for instance, we find the following key elements: Israel is represented as a wife and mother, prosecuted for her prostitution. She is repudiated and transformed into a desert where there will be no more

\footnotetext{
47 Fekkes puts this well, Isaiah: 232: 'John consciously and consistently plays one against the other, by adopting similar introductory phraseology, thematic sequences and verbal patterns.'

48 Similarly Bauckham, Climax: 338-39.

49 C. H. Giblin, 'Structural and Thematic Correlations in the Theology of Revelation

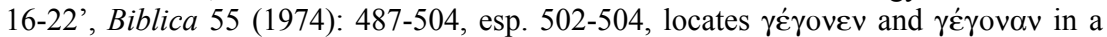
chastisement scenario with antithetical themes (requital and reward), where the first (16:17) marks 'the completion of God's wrath' and the second, at the opposing climax, 'the full realization of God's salvific, faithful and true words.'

50 On this point see D. L. Barr, Tales of the End: A Narrative Commentary on the Book of Revelation (Santa Rosa: Polebridge, 1998): 141.

51 Isaiah uses several times the refrain Immanuel (Isa. 7:14; 8:8, 10), and Zech. 8:23 may already echo him.
} 
rejoicing or celebration. She is abandoned by her lovers and desires to return to the Lord, her first husband, who woos her back, showers love upon her and gives her a dowry of righteousness and faithfulness at the new betrothal. All these motifs occur in the characterisation of Babylon or New Jerusalem, in a scenario by which the former yields to the latter. ${ }^{52}$ Or in Jeremiah 3 we find a divorce on the grounds of adultery. Here the Lord is prosecuting the kingdom of Israel (Jer. 3:8) and threatening a similar fate for Judah, accused of polluting the land with a prostitution (Jer. 3:1, 2, 9) that shouts from her forehead (Jer. 3:3; cf. Rev. 17:5). Destruction by Assyria (Jer. 50:17) may well have inspired John's motif of a falling Babylon (Rev. 17:16; 19:2). In the same context comes the first hint of Jerusalem's future restoration (Jer. 3:1118) expanded upon in later oracles (ch. 30-31 and 33). Revelation's New Jerusalem is built of materials like these.

A fate conditional upon whether the people chooses fidelity or unfaithfulness to the covenant is a constant emphasis of the prophets. They never congratulate earthly Jerusalem for current purity and faithfulness to Yahweh but repeatedly condemn her immorality, injustice and apostasy. ${ }^{53}$ Yet the very same prophets 'often utter words indicating a glorification of the city, at some indefinite future time, to a degree never seen previously'. ${ }^{54}$ Revelation updates this tradition by substituting for a restored, earthly Jerusalem (e.g. in Isa. 62) a New Jerusalem of heavenly origin and construction, dimly foreseen by Ezekiel. ${ }^{55}$

$$
* * *
$$

The data discussed up to this point must now be integrated with parallels between the two women-cities, which are of two kinds: broader compositional and thematic correlations framing the successive pictures of Babylon and heavenly Jerusalem (section vii), and compound antithetical features tying the two women-cities together

52 Other source-texts like Isa. 60-66 or Ezek. 16 and 23 appear to have contributed to the decor of Rev. 16-22.

53 For Jerusalem in the prophets, see A. J. Beagley, The Sitz im Leben of the Apocalypse with Particular Reference to the Role of the Church's Enemies (New York: de Gruyter, 1987): ch. 3, esp. 119 \& 149.

54 Beagley, Sitz im Leben: 150.

55 New Jerusalem references in Jewish apocalyptic (but with no transformed, descending Jerusalem) are listed by M. Gilbertson, God and History in the Book of Revelation (Cambridge: CUP, 2003): 137, note. 
(section viii). In combination, they lend extraordinary unity to materials that are formally quite diverse.

\section{Babylon and Jerusalem: Structural parallels}

Anticipated by the two corresponding references to a fulfilment (16:17; 21:6), the scenes where the reader encounters falling Babylon and descending Jerusalem ${ }^{56}$ develop in similar fashion. Allo emphasised how a strict and deliberate sort of parallelism linked the appearances of worldly Babylon and the celestial city..$^{57}$ For most commentators, their correspondence rests upon the twin appearances of an interpreting angel with a vision to offer (17:1/21:9) and the ensuing double transport of the seer by the Spirit (17:3a/21:10a). In fact, the structural parallelism is much more sophisticated than that, as Giblin's important study has demonstrated. ${ }^{58}$ Specifically, the beginning and end of each of the sections follow a common sequence.

First, there are symmetrical introductions:

- 1. On each occasion an angel comes forward from the same group and delivers an invitation. Revelation 21:9 reproduces twenty words

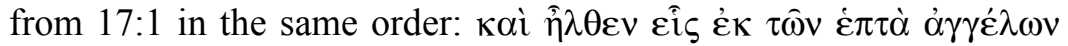

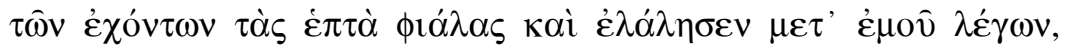
$\delta \varepsilon \hat{v} \rho 0, \delta \varepsilon i \xi \omega \sigma o l$, adding only that these are cups $\tau \hat{\omega} v \gamma \varepsilon \mu o ́ v \tau \omega v$ $\tau \hat{\omega} v \dot{\varepsilon} \pi \tau \grave{\alpha} \pi \lambda \eta \gamma \hat{\omega} v \tau \hat{\omega} v \dot{\varepsilon} \sigma \chi \alpha \dot{\alpha} \tau \omega v$, 'full of the seven last plagues'.

- 2. The angel carries the seer off in visionary ecstasy (17:3a). In

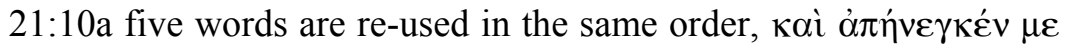
... ह $v \pi v \varepsilon v \dot{u} \mu \alpha \tau .{ }^{59}$ All that changes between the two texts is the earthly location involved, whether wasteland or mountainside, but

56 Cf. 2 Esd. 8:52-53; 10:49, whose seer finds pre-existent Zion hidden near God. Test. Dan. 5:12-13 also speaks of New Jerusalem as a place of God's glory where the righteous will rejoice. In his study Jerusalem, die hochgebaute Stadt: Eschatologisches und Himmlisches Jerusalem im Frühjudentum und im frühen Christentum (Tübingen: Mohr, 1998), P. Söllner lists the following NT or other contemporary texts where the idea of a celestial Jerusalem features: Gal. 4:21-31; Heb. 11-13; then 1 Enoch 14 and 24-27; Tob. 3-14; Sir. 36 and 51; Bar. 5; Pss. Sol. 11; the Qumran Psalms as well as $4 Q 554$ and $5 Q 15$; and finally 4 Ezr. 7-10.

57 Apocalypse: 339.

58 I am following him ('Correlations': 489-491). He calls the two visions 'paired angelic disclosures.'

59 Reader, Stadt Gottes: 267, notes the phrases' parallelism and that Revelation uses them nowhere else. 
these are correlative theatres of action. ${ }^{60}$ We may add, with J. Fekkes, ${ }^{61}$ that there is corresponding parallelism between the associates of the two women, for one has a monster as her mount (17:3b) whilst the other has a Lamb for a spouse (21:9b). The result is that the sexual natures of both women-cities are played upon, one negatively and the other positively. ${ }^{62}$ Finally, we should note how Babylon's master, the monster, is the architect of its own and the city's destruction, ${ }^{63}$ making it a skewed counterpart of the Lamb whose death secures salvation for the city of God.

- 3. Then comes a transition to the visions themselves $(17: 3 \mathrm{~b} /$ $21: 10 b$ ), with analagous antithetical development ('whore woman-

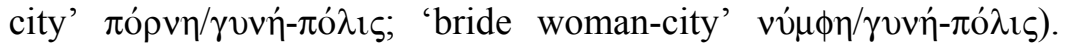
Here again their respective nomenclature brackets both womencities, Babylon (17:5) and New Jerusalem (21:10). ${ }^{64}$

Secondly, in the respective conclusions there is similar, meticulous parallelism in the number and order of the various elements:

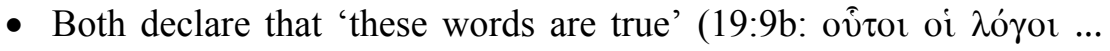
$\dot{\alpha} \lambda \eta \theta v v o i ;$ 22:6 also inserts 'faithful and' $\pi \imath \sigma \tau o i ̀ ~ \kappa \alpha i ́)$.

- In both cases, John wrongly prostrates himself before the angel.

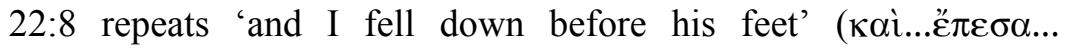

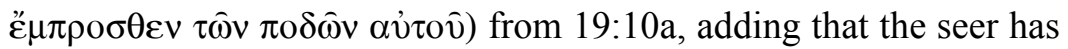
now seen and heard everything.

- Matching prohibitions identify the angel as a mere fellow-servant with John and with his brothers $(19: 10 b / 22: 9 a)$, the first of them describing the latter as bearers of the testimony of Jesus whilst the second prefers to gloss them as 'prophets and keepers of everything

60 Thus Giblin, The Book of Revelation: The Open Book of Prophecy (Collegeville: Liturgical, 1991): 161.

61 Isaiah: 94-95.

62 Thus Thompson, Revelation: 82, writes, 'Babylon and Jerusalem - feminine images of cities - are [both] clothed with fine linen and bedecked with gold, jewels and pearls $(18: 16 ; 19: 8 ; 21: 18-19,21)$, and both function as sexual partners in their respective systems $(18: 3 ; 19: 7,8)$ '. Similarly E. Schüssler-Fiorenza, Revelation: Vision of a Just World (Edinburgh: T\&T Clark, 1993): 96, 'Centuries before Revelation, the Hebrew prophets had employed the image of the bride, the wife, or the harlot either for characterising Jerusalem and Israel or for depicting other nations and their capitals'. She adds, 'the images ... do not tell us anything about the author's understanding of actual women.'

63 See R. W. Wall, Revelation (Peabody: Hendrickson, 1991): 203.

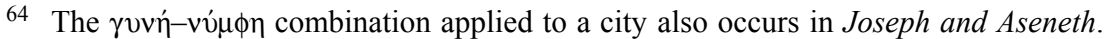
On this, see J. A. du Rand, 'The Imagery of the Heavenly Jerusalem (Rev. 21:9-22:5)', Neotestamentica 22 (1988): 65-86, esp. p. 76. 
in this book'. These angels $(19: 9,10 ; 22: 6-9)$ are of course the same as those found in the relevant introductions. ${ }^{65}$

- Each text enjoins worship of God alone ('worship God!', $\tau \hat{\omega} \theta \varepsilon \hat{\omega}$

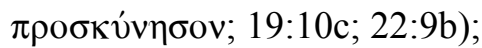

- One or more affirmations is made. The one in 19:10d, declaring the testimony of Jesus to be the spirit of prophecy, is as it were expounded by the parallel passage in 22:7-20, with several allusions to prophecy, testimony and a book.

In the diptych devoted to her story (Rev. 17-18), Babylon parodies both a woman who is the mother of Messiah and a city that is God's dwelling-place with his people. Yet when the Amazon turns into a worldly city in the second phase, our author does not forget that she remains a prostitute: $18: 3,9,16$ repeat the terms of 17:1-6 and the whore herself reappears explicitly in 19:2. A prostitute's services must be paid for and this one, by the look of her regalia $(17: 4 ; 18: 16),{ }^{66}$ is very expensive.

The textual ensemble consisting of the account of Babylon's condemnation and of the three laments over her destruction is bracketed by two parallel references to her fall: 'Fallen, fallen is

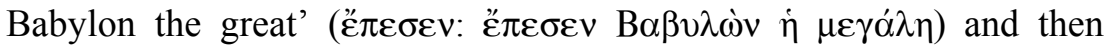
'Babylon the great city shall be thrown down' (B $\lambda \eta \theta \dot{\eta} \sigma \varepsilon \tau \alpha \mathrm{r} B \alpha \beta \nu \lambda \dot{\omega} v$ $\dot{\eta} \mu \varepsilon \gamma \alpha \dot{\lambda} \lambda \eta$ ó$\left._{\lambda} \mathrm{l} \varsigma\right)(18: 2,21)$ and by various reminders of her becoming a wasteland (18:2, 4, 19, 22-23a). If Babylon was made to fall down and be abandoned, heavenly Jerusalem in contrast was made to come down from God (or, for God to come down and live with his people). Just as Babylon's fall was anticipated in 14:8, the matching vision is similarly framed by an anticipatory glimpse (in 21:2) as well as by the description of it 'coming down out of heaven from God', following the angel's formal intervention $(21: 10 \mathrm{~b})$. And when the vision is over, two things are underlined: The absence of any impurity (21:27), in contrast to Babylon's filth $(18: 2,9 \mathrm{a})$, and the presence of God and the Lamb in the city (22:3). ${ }^{67}$

The segment in 19:11-21:8 linking Babylon's dismemberment to celestial Jerusalem's adornment is a transitional text. In fact, it is the

65 For a discussion of the parallelism, see Bauckham, Climax: 338-339.

66 Bauckham, Climax: 346-347.

67 Cf. Fekkes, Isaiah: 217: 'Babylon is fallen, deserted and forgotten. As the haunt of every manner of unclean beast and spirit, it stands in stark contrast to the New Jerusalem - the Holy City through whose gates nothing unclean can enter (21:27).' 
very last such bridging-text in the book now that the repudiation and removal of the idolatrous prostitute has opened the way for betrothal of the faithful bride. Two balancing passages effect the transition from one to the other, where the opener (19:11-21) alludes one last time to the rejection of old rebellious humanity and the finale (21:1-8) anticipates new humanity in its reconciliation to God. ${ }^{68}$

Lastly, the narrative in 21:9-22:5 expands upon the material presented in $21: 1-8$, as the counterpart to the long section dealing with Babylon.

\section{Rival women-cities: Whore and Bride ${ }^{69}$}

The opposing traits of the courtesan and the bride she parodies, draw out threads connecting the heavenly woman to the whore. ${ }^{70}$ This helps the spectator see the extent of the caricature that is Babylon and recognise the point by point retort which New Jerusalem will offer when she descends. ${ }^{71}$ An intricately worked antithesis featuring

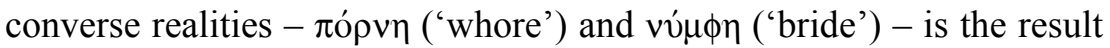
of matching portraits assembled from numerous contrary characteristics and set in a framework of corresponding introductions and conclusions. The following is a comprehensive list of multiple antithetical correlations whose cumulative force means that, in every respect, Jerusalem-the-bride is made to supplant Babylon-the-whore.

1. In both cases an identical bowl-angel invites the seer to come and watch, transports him $\dot{\varepsilon} v \pi v \varepsilon \dot{u} \mu \alpha \tau t$ and acts as interpreter for his vision

68 On this section, see J. W. Mealy, After the Thousand Years: Resurrection and Judgement in Revelation 20 (Sheffield: JSOT Press, 1992): 62-65.

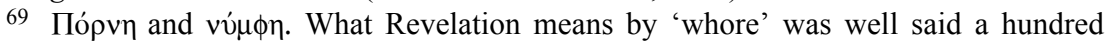
years ago by M. S. Terry, Biblical Apocalyptics (repr. Grand Rapids: Baker, 1988 [1898]): 427, 'A harlot in the prophetical sense is one who has broken the vows and bonds of the marriage covenant by any infidelity to the obligations of such union. The idolatries of the older Jerusalem were one of her most infamous offenses against Jehovah.'

70 For a summary of the threads linking Babylon and Zion, see Beasley-Murray, Revelation: $250-251$.

71 J. Sweet, Revelation (London: SCM, 1979): 301, speaks of the 'glorious new city for which that slum-clearance made room'. For Terry, Biblical Apocalyptics: 426, 'the one must be overthrown before the other can appear in her full glory'. 
$(17: 1-3 ; 21: 9-10)$ - in this fashion the scene where the first woman-city appears prepares the reader for a matching sequel. ${ }^{72}$

2. On each occasion, a woman-city is the object. The condemnation of the great 'whore' seated on many waters (17:1) prepares for the 'bride', her replacement (already in 21:2), called 'the wife of the lamb'

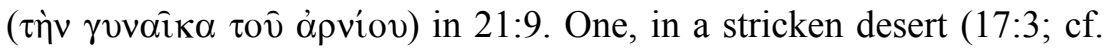
18:2), is gaudily dressed (17:4) and straddles a monster. The other descends from a high mountain, set to become a remodelled paradisal garden-city in 22:1-3 (cf. v. 19), ${ }^{73}$ and is consorted by the Lamb (21:10) for whom she has arrayed herself (21:2). In 21:18-21 this contrast $^{74}$ (cf. 17:4; 18:7-8) will be underscored by a description based on Isaiah 54:11-12 (starting with jasper, God's stone, Rev. 21:11). This portrayal fulfils the Churches' vocation (recalled in 22:16) to ready themselves for marriage $(2: 1-3: 22)$. It also reflects the glorious apparel of the heavenly Lamb-bridegroom whose acclamation, which does not transpire till 19:7, puts a crucial retrospective slant on the delineation of the risen one in 1:12-20. ${ }^{75}$

3. Being 'arrayed in purple and scarlet' (17:4) or else clothed in 'fine linen, bright and pure' (19:8) ${ }^{76}$ signifies wrong and right living respectively. This disparity helps the reader understand the amalgam 'clothed in fine linen, in purple and scarlet' (18:16) as an imitation born of presumption, dissimulating only partially the injustice for which Babylon will not fail to be condemned and destroyed. ${ }^{77}$

72 Many commentators note this; cf. R. H. Mounce, The Book of Revelation $\left(2^{\text {nd }}\right.$ edn; Grand Rapids: Eerdmans, 1998): 389. See also the comparative tables in Söllner, Jerusalem: 251-253, who has grasped the literary construction; however, I must dissent from his view (p. 260) that John is opposing Jerusalem to Rome.

73 As R. H. Gundry succinctly puts it, 'The New Jerusalem: People as Place, not Place for People', NovT 29 (1987): 254-264, 264, 'Endzeit recaptures Urzeit'. For God's garden-city is no new Eden but an incorporation of history and of the best of human aspirations and endeavour; see Ellul, Sans feu: 250-255 \& 276-279, and cf. his comments in Architecture: 234-239.

74 W. J. Harrington, Revelation (Collegeville: Liturgical, 1993): 214, is right that John intends the list of gem-stones to be a measured contrast with the whore's jewellery (in 17:4).

75 See U. Vanni, 'La Dimension christologique de la Jérusalem nouvelle', RHPR 79 (1999): 119-33, esp. p. 121.

76 Similarly e.g. H. D. Preuss and K. Berger, Bibelkunde des Alten und Neuen Testaments, vol. 2 (Heidelberg: DTV, 1984): 471, 'Die Byssusgewänder in 19:8 stehen in Kontrast zu den Hurengewändern in 17:4'.

77 J.-P. Ruiz, Ezekiel in the Apocalypse: in loc., sees 18:16 as a re-working of 17:4, 'The einst of Babylon's splendour gives way to the jetzt of the execution of divine 
4. Old Testament woman-cities predispose the reader familiar with the Jewish Scriptures to recognise both the 'whore', who conjures up Jerusalem (Isa. 1:21, Ezek. 16) but also Babylon, Edom, Nineveh, Samaria, Sodom, Tyre ... and, in contrast, the 'bride' Zion/Jerusalem. Understanding how the former may easily become the latter and vice versa is part of this awareness and the raison d'être of a new Jerusalem - which arrives in 21:10, after being glimpsed in 21:2 and expected ever since the promise of 3:12 - is to be sought in Zion indelibly graven on the palms of her Lord's hands (Isa. 49:14-16) and in wayward Jerusalem courted all over again, as Gomer was by Hosea. ${ }^{78}$

5. One woman-city - New Jerusalem, the ultimate city owing nothing to humanity for her construction - is holy $(21: 2 ; 22: 19)$ and chaste $(21: 2,9)$, like the virgo intacta Paul sees in the Church at Corinth (2 Cor. 11:1-3). She is devoid of any vice $(21: 8,27)$, has her origin in God and is draped in his glory $(21: 2,10-11)$. She also reflects his presence and communes with him $(21: 3-4,7 b)$, and the association can be read on her brow (22:4). The other woman-city is called by the nickname '[Old] Babylon' (17:5; 18:10, 18, 21), also visible on her forehead, in token of her status as first-ever man-made city (Gen. 11:49). In 17:3-6 she is dubbed blasphemous, abominable, impure, adulterous (cf. 18:9) and drunken. Communing with a poisoned chalice $(17: 4 b),{ }^{79}$ she is the enemy of all Jesus' witnesses (17:6).

6. The whole Babylon diptych (Rev. 17-18) is as though stained with the blood on the prostitute-city's hands (cf. Jer. 51:35), a guilt which seals her fate. ${ }^{80}$ It is the blood of saints and of Jesus' witnesses

judgement against her.' On the contrasts in 17:4; 18:16 and 19:8, see also Beale, Revelation: 939.

78 Traditional readings often decode Revelation's 'Babylon' as Rome, by analogy with 1 Pet. 5:13. Babylon in Revelation, however, is not a cipher but a theme. This woman-city evokes above all Jewish scripture's use of Babylon since Babel, along with various other whore-cities (Tyre in Isa. 23, Nineveh in Nah. 3:1-7). And the whore-city par excellence in the OT, from which the rest draw their force and significance, is Jerusalem herself: married to God in covenant (Ezek. 16:8), she had forsaken him through idolatry (Ezek. 16:38). For John and his readers steeped in prior revelation, 'Babylon' was Jerusalem barely disguised.

79 Perhaps parodying the Lord's Supper; see A. Pohl, Die Offenbarung des Johannes (Wuppertal, 1983): 199, 201: 'die Hure ... fordert auf ihrer Weise zum Abendmahl auf ... das Äussere und Innere des Kelches stehen in einem beissenden Gegensatz'.

80 In the Synoptic tradition, Jesus denounces Jerusalem and predicts her fall (Matt. 23:30-37); the blood of prophets persecuted and killed is the crime for which the city is to be condemned. Does Revelation reflect a form of this tradition, as H. B. Swete thought, The Apocalypse of St. John (London: Macmillan, 1907): 241 ? 
(Rev. 17:6), or of prophets and saints and of all the earth's slain (18:24). ${ }^{81}$ Such injustices ( $\left.\dot{\alpha} \delta \imath \kappa \eta \mu \alpha \tau \alpha\right)$ demand justice for shed blood, as sought by the very same victims since the breaking of the fifth seal (6:10). First declared to have been rendered in 18:20, justice is then celebrated during the transitional liturgy which follows ( $\dot{\varepsilon} \xi \varepsilon \delta i \kappa \eta \sigma \varepsilon v \tau$ ๆò

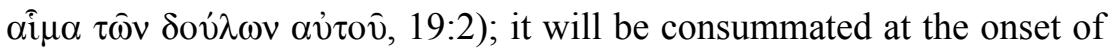
the Lamb's wedding and through the robing of his bride clothed with justice (19:7-8) in accordance with her entitlement as a 'city of righteousness' (Isa. 1:26). In the destruction of Babylon and the nuptials of New Jerusalem one event is being figured, first negatively then positively: God's faithless wife is finally being transformed into a spotless bride.

7. A combination of spiritual fornication and murder $(17: 3 b-4,6)$, crimes traditionally laid at Jerusalem's door (Ezek. 16:36-38; 23:37, $45)$, contrasts with the death of death in the celestial city where those who suffered are consoled and where neither assassin nor adulteress may be found $(21: 4,8 ; 22: 15)$.

8. Babylon is a 'whore' ( $\pi$ ópvๆ) $(17: 2,4 ; 18: 3 ; 19: 2)$, so 'whoredom, immorality' ( $\pi$ opveí $\alpha$ ) is her characteristic and it parodies the spiritual faithfulness symbolised by being wedded to the Lamb (19:7). God's people had always been invited to such a nuptial banquet (19:9) which, together with the draught of the water of life (21:6; 22:17), offers a stark contrast to the bitter cup (17:4), illicit wine (17:2; 18:3) and anti-banquet (19:17-18) associated with Messiah's judicial retribution.

9. One trait of earth- or land-dwellers, bewitched by Babylon, is the absence of their names in the book of life 'from the creation of the world' (17:8), whereas any who will enter heavenly Jerusalem are correspondingly recorded in the Lamb's book of life (21:27).

10. The great prostitute holds under her spell the kings of the earth and earth-dwellers (17:2), exploiting them while they participate in her debauchery $(17: 12,16-17)$. But the whole meaning of vú $\mu \phi \eta$ entails a reciprocal relationship between God and humanity, characterised by succour and comfort (21:3-4). The courtesan has coveted her associates' wealth (18:14), imagining that 'peoples, throngs, nations and tongues' are forever in servile submission to her $(17: 15 ; 18: 3,23)$. The bride, however, knows better for it is she who, in line with God's

81 Cf. Ellul, Sans feu: 206. 
covenant, assembles all humanity in her midst (21:3) - all, in fact, who endured the trumpets $(8: 11 ; 9: 6,10,15,18,20)$ and bowls $(16: 8-9$, $21^{82}$ ). In her, human beings are no longer lost 'nations' (20:3) but now constitute 'his peoples' (21:3). ${ }^{83}$ She knows the nations and kings will bring their tribute to her $(21: 24,26$; cf. Isa. 60:11), for this vast 'healing' (22:2) fulfils an earlier aspiration that all nations would come and bow down before her (15:4). ${ }^{84}$

11. With her seven mountains $(17: 9)^{85}$ the impostor-city aims for the heavens, ${ }^{86}$ hoping to rival the other city built, like Zion on Mount Moriah or eschatological Zion in 14:1, upon the one traditional ${ }^{87}$ high hill, the mountain of God (21:10).

12. New Jerusalem's architecture, perhaps modelled on something like the Pauline template found in Ephesians 2:19-20, conforms to the quadrangular plan of ancient Babylon (21:16) ${ }^{88}$ By having the form of

82 Thus Bauckham, Theology: 137.

83 As J. N. Kraybill puts it, Imperial Cult and Commerce in John's Apocalypse (Sheffield: JSOT Press, 1996): 206, 211, 'New Jerusalem is a metaphor of all humanity living in harmony with God and one another (cf. 5:9; 14:6).'

84 Cf. Fekkes, Isaiah: 269-270: 'The dependence of the nations on the light of the New Jerusalem in the new age is a deliberate antithesis of the former relationship between the nations and Babylon. Whereas the nations once received their direction and inclination from the evil city (Rev. 14:8; 18:3, 23), now they rely for guidance on the divine glory. Whereas they once trampled the Holy City (11:2), now they walk in its light'.

85 For many, the mention of 'seven mountains' would be obscure were it not so obviously a reference to Rome, Antiquity's famous septicollis Roma, urbs septicollis or septimontium. But if exegesis means decoding, what is to prevent Jerusalem (or any city built upon seven hills) from being just as plausible? As Beale observes, Revelation: 868, a literal reference to Rome's seven hills is, at best, secondary here. Old advice from Terry, Biblical Apocalyptics: 431, still applies: 'These seven heads of the beast no more represent literal mountains [italics mine] than do the seven heads of the dragon in xii, $3 \ldots$ unless we insist on understanding the waters of verses 1 and 15 and the scarlet-coloured beast of verse 3 as literal waters and a literal beast.' More exegetically relevant is the apocalyptic tradition of seven mountains (1 Enoch 1-36): see P. Grelot, 'La géographie mythique d'Hénoch et ses sources orientales', $R B 65$ (1958): 33-69, adapted by J. T. Milik, The Books of Enoch: Aramaic Fragments from Qumran Cave 4 (Oxford: OUP, 1976): 40 and followed by B. Malina in New Jerusalem: 22.

86 Thus Resseguie, Revelation Unsealed: 83: 'The seven mountains symbolize the archetypal human city, the tower of Babel, lurching toward the heavens ... a striking parody to the New Jerusalem that comes down ... to sit on a mountain'. Put another way, the 'what' of mountain symbolism matters, not the 'where' of mountains.

87 E.g. a high mountain (Ezek. 40:2) with a city at its summit (43:12), where the Lord's Temple towers over other mountains (Isa. 2:2; Mic. 4:1), a holy mountain, Mt Zion, God's footstool (Ps. 99:5), God's city (Ps. 48:2, 3), the site of paradise restored (Isa. 11:9; 65:25). For relevant literature, see Bauckham, Theology: 132.

88 Cf. H. Kraft, Die Offenbarung des Johannes (Tübingen: Mohr, 1974): 269. 
a cube (21:16), ${ }^{89}$ like an immense golden holy place (1 Kgs 6:20), she far surpasses any other quadrangular city with a temple at its heart. ${ }^{90}$ There is a life-giving, and not death-dealing, ${ }^{91}$ river and a central square (22:1-2; cf. $\pi \lambda \alpha \tau \varepsilon i$ in in 11:8). ${ }^{92}$ Founded on the apostles, bearers of the word (21:14), this city offers an antithesis to Babel's scrambled languages, ${ }^{93}$ although it is admittedly in biblical and other traditions and not in Revelation's text that confirmation of this is to be found. ${ }^{94}$

13. The two woman-cities' clothing and jewels correspond at a superficial level. The whore-city's gold, gem-stones and pearls (17:4 and 18:16), like Tyre before her (Ezek. 28:13), are trinkets whose counterparts are the pure gold (Rev. 21:18), precious stones (21:19) and pearls (21:21) of heavenly, transformed Jerusalem: The former indulges in self-glorification (18:7) whereas the latter's splendour reflects the glory of God $(21: 11,23) .{ }^{95}$

14. Babylon's reign will end when her yoke of oppression is smashed. In 17:16 she is laid waste, stripped, devoured and burned, while 18:8 repeats the fire motif and describes the city as plagueridden, grief-stricken and starved. God has foreseen this conclusion (17:17), for although Babylon thinks she reigns like a queen (18:7), only a day $(18: 8)$ or even an hour $(18: 16,18)$ will suffice for judgement to dissolve her 'empire'. In complete contrast, now the Lord God's reign is being established ( $\left.\dot{\varepsilon} \beta \alpha \sigma^{\prime} \lambda \varepsilon v \sigma \varepsilon v, 19: 6\right)$, a fully acquitted bride is being made ready and in her definitive, perfected state $(21: 2)$, she will reign for ever and ever (22:5).

89 Or, if a pyramid is meant, then perhaps an antithesis is being drawn with Babylon's ziggurat. See J.-P. Charlier, Comprendre l'Apocalypse, vol. 2 (Paris: Cerf, 1991): 226.

90 As B. Malina notes, New Jerusalem: 46-47, oriental cities functioned as the divinity's place of residence, with buildings for worship at the centre: 'Here (Rev. $21: 16)$ that holy of holies has become a cosmic city, and the cosmic city a cosmic holy of holies' (p. 56).

91 The river of 22:1 contrasts the torrent spewed out by the dragon but swallowed by the earth (12:15-16) and the Euphrates that traversed Babylon $(9: 14 ; 16: 12)$; on this see Resseguie, Revelation Unsealed: 84-85.

92 Helpful discussion of how New Jerusalem transposes old Babylon's topography is found in Gundry, People as Place: 262; Kraft, Offenbarung: 272; Malina, New Jerusalem: 45-47, 53; Schüssler-Fiorenza, Just World: 113-114.

93 Ellul, Sans feu: 281.

94 A. Yarbro Collins, The Apocalypse (Dublin/Wilmington: Michael Glazier, 1979): 148-149, is one of many to ask how well John knew Babylon, given New Jerusalem's striking similarity to Herodotus' Babylon.

95 On all this see Beale, Revelation: 1119: 'Revelation 21 portrays the true community of God in contrast to and in replacement of the false community of the world' (italics mine). 
15. Between the first panel devoted to the prostitute (17:1-18) and the second entitled 'Babylon the great' $(18: 1-24)$ comes an important transitional detail: The dubious kingdom $(\beta \alpha \sigma \iota \lambda \varepsilon \dot{i} \alpha)$ attributed to each (17:18) makes the adulterous woman and the great city one. However, once the bride-city appears $(21: 2,9)$, and the true conqueror claims his or her inheritance (21:7), the equivalence of feminine and urban imagery will no longer need to be spelt out.

16. Babylon has become the demons' hide-out and the unclean animals' lair (18:2). This is a foil both to the dwelling of God (21:3) and to the throne of God and the Lamb (22:3) in the holy city.

17. In the picture of the devastated whore-city, where 17:2 has been reworked for 18:3, the 'impurities of her adultery' (17:4) characteristic of the now despoiled whore $(17: 16)$ become a picture of threefold impurity ${ }^{96}$ at the start (18:2) and of sorcery at the end (18:23; cf. $\left.9: 21^{97}\right)$. Sorcerers figure explicitly among the excluded from the holy city $(21: 8 ; 22: 15)$ which is characterised by the purity of righteous deeds (19:8) and by transcendent glory (21:11).

18. Since Babylon's accumulated sins almost reach to heaven (18:5), it is vital to break with her, her sin and her plagues (18:4) in order to escape the verdict that sanctions her ${ }^{98}$ (18:5-7a). Such renunciation represents the prior condition for citizenship in New Jerusalem, makes a share in the corresponding rewards possible (21:4) and opens access both to the promised inheritance awaiting beneficiaries (21:5-7) and to final beatitude in the city of eternal justice and life (22:14).

19. The great city's antithetical counterpart (18:19), embroiled in Revelation's plot since 11:8, is the beloved city, besieged but liberated in 20:9, which anticipates New Jerusalem. ${ }^{99}$

20. The symbolic actions of the angel, accompanying his words (18:21-24), interpret Babylon's downfall in terms of privations which distinguish her from perfected New Jerusalem and reproduce almost word-for-word Jerusalem's desolation as seen by Jeremiah (Jer. 25:10). The music and song which gladden Zion (14:1-3) and the resplendent

96 Reading the same variant as Nestlé-Aland ${ }^{27}$, where spirits, birds and beasts together squat in the ruins.

97 Isa. 47:9 has Babylon's magicians and Nah. 3:4 those of Nineveh.

98 Cf. sinful Sodom (Gen. 19:12-22), Babylon (Jer. 50:8; 51:6) and Jerusalem/Judea in the Gospel tradition (Mark 13:14).

99 G. B. Caird, The Revelation of St. John the Divine ( $2^{\text {nd }}$ edn; London: A\&C Black, 1984): in loc., speaks of 'a descending-from-heaven kind of city'. 
holy city $(21: 11,23-25)$ are gone from Babylon $\left(18: 22^{100}\right)$, where total darkness reigns (18:23) and no bridegroom's song rings out within her bounds (18:23). Everything about New Jerusalem, on the other hand, evokes a wedding celebration where joy and delight surround the Lamb and his bride $(19: 7-9 ; 21: 2 ; 22: 17)^{101}$ and where the tragic circumstances that recall Babylon - encapsulated by 'mourning', 'weeping' and 'pain' - are simply no more (21:4).

21. Babylon's seduction of the earth's kings, earth-dwellers and all nations $(17: 2 ; 18: 3,23)$ is summed up as having corrupted the earth with her adultery (19:2). New Jerusalem is different, causing the nations to walk in her dazzling light. ${ }^{102}$ This fulfils the Servant's vocation (Isa. 42:6; 49:6) ${ }^{103}$ to be a guide to the peoples (Isa. 51:4; $60: 3)$ and also the lamp-stands' light-bearing function (2:1-3:22) as witnesses (11:4) summoned to shine forever like the Lord they represent. An illumination involving neither sun, moon nor stars $(21: 23 ; 22: 5)$ means the bride is superior even to the glorious woman clothed with the heavenly luminaries (12:1).

22. In 19:11-17 the monster linked to the whore $(17: 3,11,13,16-$ 17) is captured and exterminated (19:20) by the messianic horseman. $\mathrm{He}$ is none other than the Lamb-bridegroom, mentioned seven times throughout the course of the vision of the holy city $(21: 9,22-23,27$; $22: 1,3)^{104}$ who enters the city as a victorious king prior to the arrival of his betrothed, delayed until 21:2 (cf. Ps. 45). ${ }^{105}$ Negatively, all adversaries and obstacles $(19: 20-21 ; 20: 2-3,10,14-15 ; 21: 1)$ belonging to the first things $(21: 4)$, like the curse hanging over the fallen world they were part of (22:3), are eliminated. Positively, a new world (21:1$7)$ is created by an efficacious word $(21: 5 ; 22: 6)$, ushering in the new relationship between God and humanity which is described from 21:9 onwards.

\footnotetext{
${ }^{100}$ As was the case for Tyre (Ezek. 26:13) or more generally the earth (Isa. 24:8).

101 Prévost, Apocalypse: in loc., finds in 18:21-24 the contrasting fates of Babylon and New Jerusalem.

102 Thus also Bauckham, Theology: 131.

103 See P. Poucouta, 'La mission prophétique de l'Eglise dans l'Apocalypse johannique', NRT 110 (1988): 38-57, esp. pp. 47-48.

${ }^{104}$ For I. T. Beckwith, The Apocalypse of John (New York: Macmillan, 1919): 759, 'the celestial city is distinctively the city of the Lamb in his transcendent glory' in contrast to the woman-city on the monster (17:3).

105 Cf. Mealy, Thousand Years: 64-65.
} 
23. The lake of fire and sulphur $(19: 20 ; 20: 10,14-15)$ is an antidestination for those not enrolled. ${ }^{106}$ Anti-god forces are thrown into it 'alive' to be tormented there day and night for eternity, which is equivalent to second death. But heavenly Jerusalem welcomes within her imposing walls, contrasting Babylon's ruins, those whose names are recorded in the Lamb's book of life (21:27b). She offers them lifegiving water and fruit, or a share, of the tree of life $(22: 2,17)$, in other words life with God who is all in all and with the Lamb (21:3, 7, 22; 22:3-5) - life that was impossible in Babylon.

\section{Conclusion}

It is not merely the cumulative weight of so many often subtle antithetical correspondences between Babylon and New Jerusalem that is significant, but their careful preparation from the opening septet onwards. This snowballing effect means that heavenly Jerusalem, in Revelation's story, is a richly cumulative picture of God's saving involvement in the triumphs and tragedies of human history and civilisation. This is seen particularly in the positive, negative and mixed diagnosis of the life and experience of the Churches in seven Asian cities, as given by Jesus the faithful witness (2:1-3:22). Objects of his love and atonement, a kingdom and priests in the service of his Father (1:5b-6) and bearers of the witness of Jesus whom they follow (1:9 etc.), these communities constitute a people who already share in what Messiah, who has died and been raised, has achieved for them.

In assembly together on the Lord's Day, their worship as the prophecy is read blesses them $(1: 3 ; 22: 7)$. The liturgy rehearses past redemption (1:5b), actualises ongoing benefits of being in Jesus through the Spirit $(1: 9-10 ; 2: 7$ a etc.; $17: 3 ; 21: 10)$ and anticipates a final salvation which is 'near' $(1: 3)$ and 'soon' $(1: 1 ; 22: 7,12,20)$ - thus bolstering their faithfulness and steeling their perseverance as 'overcomers' (2:7b etc) in the here and now. In view of the heaven upon earth to be experienced when Jesus finally comes to make all things new, every time the new covenant people in the earthly city sings its new songs in praise of the reigning Lamb, there is a foretaste

106 As Beasley-Murray says, Revelation: 304, John depicts 'life outside the city (21:27) in contrast to life inside the city (21:24-27), the separation being effected by the city's wall'. 
of the banquet to come. As a place where an unblemished people sees God and the Lamb face to face, in fulfilment of ancient promises (21:3), New Jerusalem is therefore the perfecting of all that was defective in the experimental Church-cities of Roman Asia. Although they will fall like Jezebel or Babylon-the-whore, God's city will be the realisation of all that held promise in them: such is the logic of the entire women-cities theme in Revelation. ${ }^{107}$

With a splendour more glorious than even that of the celestial mother-figure and numerous positive characteristics which neutralise to the finest detail everything that typified garish Babylon, the celestial city is a veritable Babylon rediviva. ${ }^{108}$ The proud proto-city, Babylon the great, had thought herself eternal (18:7; cf. Isa. 47:7-8), ${ }^{109}$ only to fall in rebellion and rise no more. It is New Jerusalem, fashioned by God himself, which now wears the mantle of the ultimate, teleological ${ }^{110}$ city, the only truly 'great city' in the end, whose impossible dimensions (21:16-17) reflect her ability to unite God and humanity in eternal communion (21:3). By supplanting Babylon, heavenly Jerusalem likewise erases the memory of revolt, tyranny and oppression in Babel or Sodom, Egypt or Tyre.

Most significantly she is the ennobling of historical Jerusalem, ${ }^{111}$ socalled 'holy city' but infamous covenant-breaker and the target of repeated prophetic denunciations for being the worst of all evil cities. As a bride-city she replaces the whore-city, earthly Jerusalem, descending onto an obviously vacant site. In this way she fulfils a high calling whose latest recipients, in salvation history, are the Churches-in-cites of Ephesus and environs to whom John writes. By faithful discipleship in their cities, in response to their Lord's revelation, these communities

107 On this see also Bauckham, Theology: 126.

108 D. Georgi, 'Die Visionen vom himmlischen Jerusalem in Apk 21 und 22' in Kirche: Festschrift für Günther Bornkamm zum 75. Geburtstag, ed. D. Lührmann and G. Strecker (Tübingen: Mohr, 1980): 351-372, esp. p. 370.

109 See Bauckham, Climax: 344.

110 Malina, New Jerusalem: 63, says eloquently: 'Descending from the sky, the new

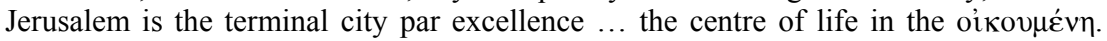
The God who descends and resides in the city is now 'our' God, not just the God of Israel'. Bauckham, Theology: 132-143, offers a fine analysis of New Jerusalem in terms of place, people and divine presence.

${ }^{111}$ In an otherwise generally persuasive argument, Bauckham (Theology: 127ff.) claims that Revelation shows no interest in earthly Jerusalem. This needs qualification for, as we have seen, and as Bauckham is himself aware (Climax: 207-209), the perfected woman-city and her historical predecessor are inextricably linked. 
may fulfil a vocation which, until now, had been continually betrayed in the history of God's people and of humanity. By faith, they may become a colony of the true woman-city and offer a glimpse of heavenly New Jerusalem upon earth. 